\title{
Examining the authority and authority of judges in terms of independence, science and ijtihad in jurisprudence and law
}

\section{Examinar la autoridad y la autoridad de los jueces en términos de independencia, ciencia e ijtihad en jurisprudencia y derecho.}

\author{
Alireza Mahdavi \\ PhD Student in Theology, Jurisprudence and Fundamentals of Islamic Law, Islamic Azad \\ University, Mashhad Branch, Iran.

\section{Hossein Ahmari} \\ Department of Theology, Jurisprudence and Fundamentals of Islamic Law Islamic Azad \\ University of Mashhad Iran.

\section{Mostafa Rajaei Pourazo} \\ Department of Theology, Jurisprudence and Fundamentals of Islamic Law Department, Islamic \\ Azad University, Mashhad Branch, Iran.
}




\section{Summary}

One of the reasons that makes the position of the judiciary valuable is the issue of the implementation of Islamic justice, which we can only achieve by having fair judges with the condition of judicial independence; And this issue is one of the important goals of this research and is of special importance in the current era; And it doubles the need for our attention and research. According to the subject of the research, the method of collecting materials is documentary and library method in such a way that first the desired sources are studied and where necessary, research is done on the material. The research method is descriptive-analytical. First, the required resources are selected from electronic libraries, articles and dissertations, and after studying and separating the required material, based on the inductive method, analytical and necessary filing of the required resources is completed and compiled. This research tries to answer the question: what is the jurisprudential and legal study of the independence, science and ijtihad of judges? And what are the legal jurisprudential bases of judges' independence? What we have reached about the nature of the judge's knowledge in this study is that the expressions in Articles 211 and 212 of the Islamic Penal Code of 1392 indicate that from the legislative point of view, what is the basis for producing knowledge for the judge is evidence and the UAE typically The science is the result of judicial research. Also, the results of the research showed that the expressions in Articles 211 and 212 of the Islamic Penal Code of 1392 indicate that from the legislator's point of view, what is the basis for producing knowledge for the judge is evidence and the UAE is typically knowledgeable as a result of judicial investigation. In the current laws and procedures of the judiciary, the mujtahid of a judge is not considered a necessary condition for holding the position of judge.

Keywords: authority and power of the judge, knowledge and independence of judges, ijtihad and knowledge of the judge, judgment in jurisprudence, judgment in law.

\section{Resumen}

Una de las razones que hace valiosa la posición del poder judicial es el tema de la implementación de la justicia islámica, que solo podemos lograr con jueces justos con la condición de independencia judicial; Y este tema es uno de los objetivos importantes de esta investigación y es de especial importancia en la era actual; Y duplica la necesidad de nuestra atención e investigación. Según el tema de la investigación, el método de recolección de materiales es el método documental y bibliotecario de tal manera que primero se estudian las fuentes deseadas y, en caso necesario, se investiga el material. El método de investigación es descriptivo-analítico. Primero, se seleccionan los recursos requeridos de bibliotecas electrónicas, artículos y disertaciones, y luego de estudiar y separar el material requerido, con base en el método inductivo, se completa y compila el archivo analítico y necesario de los recursos requeridos. Esta investigación intenta dar respuesta a la pregunta: ¿qué es el estudio jurisprudencial y jurídico de la independencia, ciencia e ijtihad de los jueces? ¿Y cuáles son las bases jurídicas jurisprudenciales de la independencia de los jueces? Lo que hemos llegado sobre la naturaleza del conocimiento del juez en este estudio es que las expresiones de los artículos 211 y 212 del Código Penal Islámico de 1392 indican que desde el punto de vista legislativo, cuál es la base para producir conocimiento para el juez es La evidencia y los EAU típicamente La ciencia es el resultado de la investigación judicial. Además, los resultados de la investigación mostraron que las expresiones en los artículos 211 y 212 del Código Penal Islámico de 1392 indican que, desde el punto de vista del legislador, lo que es la base para producir conocimiento para el juez es la evidencia y los Emiratos Árabes Unidos típicamente están informados. como resultado de una 
investigación judicial. En las leyes y procedimientos actuales del poder judicial, el mujtahid de un juez no se considera una condición necesaria para ocupar el cargo de juez.

Palabras clave: autoridad y poder del juez, conocimiento e independencia de los jueces, ijtihad y conocimiento del juez, juicio en jurisprudencia, juicio en derecho.

\section{Introduction}

For many, the question may arise as to whether the judge should be independent or not, and whether the judge's knowledge should be limited to ijtihad. If ijtihad is necessary for the judge, then how is the urgent need for a judge and the absence of a mujtahid eliminated in the courts? And what are the evidences and bases that distinguish an independent judge and a mujtahid? Today, due to the wide range of judicial needs for judges, it has provided the ground for authorized judges or consolidation in this system to be able to issue a fair verdict using judicial evidence, relevant experts and mujtahid fatwas and advice as needed. This article also seeks to address the principle of judicial independence that every judge should have in order to be able to make a fair judgment without any reluctance or power; And considering that independence is very important for the judge and the judiciary, it has made this research necessary, so in the definition of a judge it is said that a judge is actually someone who has all these characteristics and whoever is a judge should $\mathrm{He}$ has the necessary conditions to become a mujtahid or a mufti and a jurist, but the opposite is not true, that is, a jurist, a mujtahid and a mufti do not have to meet all the conditions that a judge must have. (Al-Sherbini Khatib, Mohammad, Mughni Al-Muhtaj to know the meanings of the words Al-Minhaj. Vol.

It has also been said: "Judging is permissible and sometimes obligatory among Muslims, and if the conditions for the obligation to judge are not met, that is, there are several judges who have the capacity to judge, it is mustahab." "Judgment is sufficient for those who qualify for such a position." (Hali, Ibn Idris, Muhammad ibn Mansour ibn Ahmad. Al-Sarair al-Hawi for writing the fatwas. Vol. 2, p. 152).

Judicial independence is more important than other conditions because it is the supreme of all conditions of judgment and the realization of divine justice; And all the conditions pursue a common goal, namely the guarantee of the rights of the people and the establishment of social justice, which are not achieved by independence and impartiality in judgment. Therefore, in this article, we seek a detailed study of the subject of research "Legal jurisprudence of the independence and impartiality of judges" from different perspectives (Islamic law, jurisprudence, law and law) with a common goal between them (achieving justice and establishing the impartiality of judges).

Therefore, we briefly state that the independence of judges does not mean arbitrariness and lack of consultation and use of valid jurisprudential arguments, but the opposite is the case. It has been narrated from the Holy Prophet (PBUH) that he said about the use of the knowledge of others: The wisest people are those who gather the knowledge of all people with their knowledge. (Qomi, Saduq, Muhammad ibn Ali ibn Babawiyyah. Amali. P. 13).

Also, the independence of the judge does not mean ijtihad to vote; Because this kind of thinking, according to the Sunnis, is the same as legislating and legislating the law; That is, the mujtahid 
should make a ruling that is not in the book and tradition with his own thoughts and opinions. This is called "vote ijtihad". This type of ijtihad is forbidden by the Shiites. Therefore, independence can be considered based on the current situation, including three issues:

1- Independence in not influencing or influencing the power of third parties and even threatening the judiciary.

2- Independence in not threatening the judge with the verdict issued and observing equality or observing all the rulings related to judging the rights of the parties.

3- Independence in the inner state of the judge, which includes nervous disorders, increased working hours, physical and mental illnesses, etc., which cause disorders in the judgment.

Therefore, the judiciary is an independent power and the meaning of its independence is that if a ruling is issued by judges, no one, not even a mujtahid, has the right to violate or interfere in it, and no one has the right to interfere in the judiciary, and interfering is against the sharia and prevention. The verdict of the judges is also against the Sharia; And judicial independence means that if a verdict is issued, that verdict will probably be upheld It has a reference and no one else has the right to interfere.

Finally, judging without the independence of judges and observing equality and realizing the right and not paying attention to arbitrariness and false analogy, does not make sense and independence can not be separated from the judiciary and create any kind of disruption in the judiciary, ie removing the sharia and legal rights of individuals. Considering that this has no place in Islamic judgment. Therefore, in this study, we discuss the issue of independence from the perspective of Sharia (book, tradition, consensus and reason) and most of the famous and expert jurists such as Sheikh Ansari, Sahib Jawaher, the late Karaki, the late Mohaghegh, the late Ameli and Allameh and the late Imam Khomeini, jurists Contemporary. We will explain the title and finally the dependence of laws and legal views on the goals and interpretations of Islamic law in detail.

Of course, the late Ameli Karki quotes about the justice of judges that the famous jurisprudential saying is the obligation to observe equality in these matters; And this obligation is going on between the lawyers of the parties. (Ameli Karaki. Ali Ibn Hussein. Rasael Mohaghegh Karaki. Volume 3. p. 89).

Some also believe that it is not necessary to observe the settlement of the parties in the heart desire. (Kashf al-Latham wa al-Baham on the rules of rulings. Volume 10. p. 479. And some, such as Sheikh Ansari, believe that it is makrooh for a judge to pay attention (too kindly) to one of the parties. (Sheikh Ansari. Al-Qada fi al-Shahadat. P. 114) It is imperative that judges always be strong in their independent thinking and will, and in their position and decisions, and have equal power over the parties, and not be influenced by any of the political and economic powers. The extraordinary importance of the independence and impartiality of judges and its sensitive position in the Islamic system; which in this study, while examining the historical course of judging in different societies until the mission of the Holy Prophet (PBUH) based on Islamic jurisprudential arguments or even religions Different and Qur'anic views on the status, independence and impartiality of judges are discussed and in this regard, while explaining the concept, dimensions and principles of the principle and providing a correct reading of it, to explain its jurisprudential position, the conditions and obstacles to its realization in the Iranian judicial system Let us examine whether the principle of independence and impartiality of judges in the 
Islamic government is in accordance with the Islamic Sharia discussed in this article. This question will be specified at the end of the research.

\section{Background research}

In an analysis conducted by Amiri (2013) entitled "The Importance of Judgment and Independence of Judges in Islamic Law" it is pointed out that judicial independence, which today is one of the roots of constitutional rights and independence of powers in the constitution of modern countries. It is known to have a historical connection with Islamic law. The basis of judging in Islam goes back to the two elements of authority and responsibility. Judges in the early days of Islam had special powers, which was complete independence, and no authority, not even the caliphs, had the right to interfere in the judiciary.

Movahedi Moheb (2009) in a study entitled "Judge ijtihad in the Iranian judicial system" concluded that ijtihad is an undeniable virtue in line with the goals of the Islamic legal system and the constitution, and non-mujtahid judges must be supported by Islamic jurisprudence and principles of Islamic law. The current judicial system and laws are well known.

In an analysis conducted by Kalantari and Salmanpour (2017) entitled "The place of the judge's knowledge in proving the criminal case in Iranian law", researchers concluded that the sensory documents of the judge issuing the sentence can not be considered typically scientific. The knowledge of the judge must be based on documents that are typically scientific and of the kind of examples mentioned in the note below Article 211 of the said law.

Heidari (2014) in a study entitled The validity of the judge's knowledge in issuing criminal sentences in the Islamic Penal Code adopted in 1392 states that a review of the articles of the 1392 law shows that the knowledge and persuasion of the judge in this law is placed along with other evidence And is considered a criterion for proving a criminal case. Although this issue has a history in ta'zir, but it is considered as an innovation of the criminal legislator within the limits and retribution, so that the legislator in these crimes can act on legal grounds, provided that the judge does not have the knowledge to the contrary. $\neg$ Acceptable. Although from the jurisprudential point of view, the judge should be a mujtahid, but in the current situation and the lack of a mujtahid for this position and on the other hand, the society urgently needs a judge, so with the permission of the supreme leader who is the general deputy of Imam (AS), people with the necessary arrangements and judicial instructions. Officials are appointed as authorized and consolidated judges.

\section{Limitations of judicial independence}

As stated, judges in decision-making must be protected from the undue influence and interference of incompetent forces and forces; Whether from the direct involvement of the political and executive forces of the country or the indirect involvement of public opinion and mass media. In Islamic law, jurists are of the opinion that the judge can act on his knowledge in cases where he has knowledge of the accuracy and rightness of his claim (Sangalji, 2001: 141); Therefore, in the past, when there was no new judiciary, science-based voting was acceptable in our country. Of course, this issue has led some Western jurists to believe that the issuance of a verdict by a Muslim judge is based only on his knowledge and he has absolute authority to carry out his demands (Alizadeh, 2008: 107). It should be noted here that in addition to the fact that jurists consider only 
knowledge of the subject as a condition for citing the knowledge of a judge, the commentary to Article 3 of the Code of Judicial Procedure, which is an unprecedented provision in our law, clarifies at least the legal provisions:

"If the judge is a mujtahid and finds the law to be against the law, the case will be referred to another branch for investigation." Therefore, he cannot rely on science that is against the law. In addition, one of the conditions of a judge in jurisprudence is justice. Justice in this position means correct orientation, trustworthiness, chastity with incest and security.

To fear oneself is from pleasure and anger (Alieh, 1406: 49); These cases themselves can be conditions for guaranteeing the right trial. Therefore, a judge cannot issue a verdict under the pretext of independence, creativity, or intuitive arguments, contrary to the rule of law and certain legal principles such as the principle of innocence. In other words, his independence is valid to the extent that it does not become a means of violating the rules and principles of law as well as individual rights, otherwise, in addition to violating the sentence in higher authorities, it leads to disciplinary action and even in some cases, criminal prosecution or civil liability.

It may be argued that the judge, due to his independence, is not required to follow the judicial procedure, except in special cases (Farkman and Vegrish, 2003: 159); But ensuring the equality of individuals before the judiciary governs the judge's adherence to judicial procedure and limits his or her full independence; Because a completely independent court makes regular social behavior and economic activities of society impossible. If the outcome of any case is only the judge's understanding and conflicts with the decision of other cases involving similar issues, citizens do not want and can not go to court (Burbank, 2003: 326); Therefore, judicial independence is not absolute; That is, the courts may not, as they deem appropriate, issue a judgment, whether external or internal, potential or actual. Human beings are selfish and corrupt, and even the moral standards of individuals are variable, so you must think of a way to monitor the judicial process and determine the limits of independence. The principle of accountability is one of the methods of limiting the absolute independence of the judge and means responsibility for the state or quality of judicial behavior that has deviated from conventional standards (Foster, 2006: 98). Independence and judicial responsibility are complementary concepts that can and should be combined. In other words, they are two sides of the same coin, so that the responsible judiciary, which has no independence, is weak and powerless, and the independent judiciary, which has no responsibility, is very dangerous (Burbank, 2003: 325). In general, those who have the will and are the source of the decision should be held accountable; If the judge does not have independence, holding him accountable for his actions and decisions is against justice. Also, the accountability and responsibility of the judge is a democratic principle (Federico, 1998: 373). This means that the judge, while independent and dealing with the judiciary, must be accountable to the people who own the government and the country; But it is important to know which authority oversees the actions and conduct of judges. The general principle is that the appointing authority of judges is the most competent authority to oversee the actions and conduct of judges. Of course, some jurists oppose the judge's liability for minor errors. As the responsibility arising from the fault of the judge according to Article 171 of the Constitution is considered incompatible with the necessities of this important job if the fault is taken in its usual meaning (Katozian, 1387: 389). This view is correct in that the interveners in the independence of the judge may allow this intervention to cover his responsibility; Because the independence of the judge is mostly threatened by the officials who supervise the work of the judge. Therefore, in order to solve this problem, the authority to investigate judges' violations must be independent and within the justice system, that is, it must be a judicial authority and its members must consist of judges rather than 
executive authorities; Because it does not make sense for people who do not have independence themselves and do not have job security to be the reference for investigating a judge's error; In this case, the executive can be a means of suspending and dismissing the judge. Also, in principle, accusing and dismissing judges should not be a reaction to the content of their judicial decisions; But only for its legal purpose (Burbank, 2003: 329).

For this reason, the Human Rights Commission rejects its concern about the dismissal of two judges by the President of a country in order to prevent the interference of the executive branch and declares: UN, 149). Article 17 of the Basic Principles on the Independence of the Judiciary states in the Charter that "any charge or claim made against a judge concerning his or her jurisdiction or profession shall be subject to the same fair trial as an independent tribunal."

In addition, according to Article 42 of the bill amending part of the Law on the Principles of the Organization of Judiciary and the Employment of Judges, it is not possible to prosecute a judge before he is suspended by the Supreme Disciplinary Court. Because a judge without immunity from prosecution has no job immunity and his independence is easily violated. In any case, a single institution with the same standard should deal with judicial violations. The existence of similar and parallel institutions, which can permanently remove the judge from service and their verdict is final in some cases, is against judicial independence (Shams, 1387: 173). Thus, in a judiciary whose judges are so easily disqualified, the concept of judicial independence is severely distorted.

\section{The concept of judges' knowledge in jurisprudential and legal terms}

Science means knowing and being aware of the nature of events and phenomena in the environment. From the point of view of logic, it is a quality science that is created by combining the current single feeling with the previous feelings in the human mind. This quality and manner is called perception or awareness, or the result of a foreign object in the mind, which has also been interpreted as cognition and science (Mojtaba, 1987: 20).

Science in jurisprudential terms means certainty and certainty, which is also called ordinary science (Jafari Langroudi, 1367: 4/563). In this regard, Allama Hali has said in the commentary of the Mu'tam'in: (Hali, 1411: 697) and also Imam Khomeini have said in Tahrir al-Wasilah: (Khomeini, 1366: 539). In the principles of jurisprudence, the science of cutting is the opposite of suspicion, and its truth is nothing but the development of reality and the truth as a whole. It should be noted that cessation is a state of mind in which something is known to a person and is opposed to suspicion, doubt and possibility. In other words, it is a dogmatic cut in which the possibility of error and wrongdoing is not given (Bayhaqi, Bita: 106). Of course, in jurisprudence and law, reaching this knowledge in which no unknown remains is not meant, but it is an ordinary and conventional science that is used in law as a means of resolving and resolving disputes (Ahani, 1381: 38).

In judicial issues, two types of science come to mind: first, it is a science that has stated the rules and regulations and discusses the duties and responsibilities of individuals, and second, it is the judge's knowledge of the disputed subject and the disputed reality. It is possible for this knowledge to be obtained as a result of experiences and study of sciences, etc. with a series of conclusions or through the study of the case and the explanations and arguments of the parties for the judge. Which is basically the proof of a claim from the manifestations of ordinary science. In 
order to clarify this issue, ordinary or certain science and personal or acquired science are explained below:

Ordinary or certain science

Personal or product knowledge

Regarding the knowledge of the judge, there are four sayings among Shiite jurists:

- The authority of the judge's knowledge only in the rights of the people

- The authority of the judge's knowledge only in the rights of God

- The absolute authority of the judge, which is a well-known opinion.

Lack of absolute authority of the knowledge of the judge, which is the opinion of Ibn Junaid.

The validity of the judge's knowledge

Most jurists agree on the validity of the knowledge of the judge, but disagree on the extent of influence and its subjects and conditions. From this perspective, different statements are examined in this regard:

1. Credit in the right of the people

2. Credibility in the right of God

3. Absolute validity

4. Validity in injury and adjustment

The positive value of the judge's knowledge in jurisprudence and law

The positive value of the knowledge of the judge in criminal jurisprudence has always been discussed and disputed among jurists. Some Sunni jurists (Novi, 1412: 8/140; Sharbini, 1415: 4/399) and most Shiite jurists (Alam al-Huda, 1415: 487; Rashti, 1401: 91) with reference to some verses and hadiths that are often They are in charge of financial and human rights claims, they consider the knowledge of the judge to be valid and of positive value; Although they differ in the degree of influence, territory and its conditions (Jabei Ameli, 1386: 6/385; Tusi, 1387: 8/167). Some other jurists are opposed to this view in general and some are opposed to the so-called crimes of God. According to the opponents, the permission to cite personal knowledge provides the basis for issuing a verdict based on the air of the soul and puts the ruler in suspicion of accusation (Ibn Qadameh, BT: 9/53; Ibn Rushd, 145: 2/ 392) It has also been said that the judge's knowledge is sensory knowledge and cannot be presented as evidence to the litigant, and therefore the right to dispute is taken away from the person against whom the evidence is against. In the event of a dispute, the judge will be reduced to one party (Sanhori, 1952: 2/27), and this is a gross violation of the rules of procedure. On the other hand, it can be said that the impermissibility of judging a judge based on his knowledge is one of the branches of the rule of "al-bina al-al-madai". The requirement of this rule is that the task of proof is always the responsibility of the plaintiff, not the judge and others. However, a promise based on the knowledge of a judge has a stronger argument and a more logical justification. If confession, testimony, and oath were matters of worship and confinement, the issuance of a sentence was not permissible except on the basis of 
them; But these reasons are merely the means and ways of discovering the truth and creating knowledge in the judge. His knowledge is the criterion for knowing the truth and is stronger than the testimony that is useful for suspicion (Shokani, 1255: 8/289). If the judge's reliance on his knowledge in issuing a verdict causes slander and suspicion, accepting the evidence of the plaintiff or the oath will also be subject to the same slander (Alam al-Huda, 1415: 493). In a rational analysis, as Abul Salah Halabi has said, the correctness of the verdict based on confession, evidence and oath is a branch of obtaining knowledge on their validity; If the judge's knowledge is invalid, the issuance of a verdict based on other evidences will not be valid (Halabi, 1403: 3/420). This statement is based on the assumption that the arguments have no intrinsic validity, but their validity depends on the judge's assurance of their accuracy and authenticity (Mohaghegh Hali, 1411: 3/543). In any case, the science that the judge can rely on is scientific (Shokani, 1255: 9/197). Therefore, with the realization of the judge's knowledge, which is accompanied by expressions of confidence, no other evidence is needed for the litigation chapter and it suffices that knowledge is sufficient to issue a verdict and makes it unnecessary from other evidences (Dadashi and Feyz, 1395: 109). It seems that the ruling of Article 211 of the Islamic Penal Code, which stipulates that "the knowledge of a judge is the certainty obtained from the documents in the matter before him", has the same meaning.

In Iranian criminal law, the judge's knowledge has been declared valid as one of the proofs of the claim in general and the reason for proving the crime in particular. Among other things, the Islamic Penal Code adopted in 2013 mentions the knowledge of the judge as one of the ways to prove a crime. Article 160 of this law states that "the evidence of a crime is confession, testimony, oath and oath in cases prescribed by law and the knowledge of the judge" as well as in accordance with Article 161 "in cases where criminal litigation with religious evidence such as confession and testimony "It is proven that the judge will issue a verdict based on them, unless he has the knowledge to the contrary." 160 and 161 and their jurisprudential origin - it can be concluded that the knowledge of the judge can be cited both in the right of God and in the right of the people. According to the definition according to Article 211 of the Islamic Penal Code, "the knowledge of the judge is the phrase Certainty is the result of Bin's documents in what is presented to him. "By studying such a science in accordance with the second part of the mentioned article, and as the following note indicates, there are evidences and emirates that typically lead to certainty, such as Expert Theory, Site Inspection, Local Investigations, Informed Statements, Officers' Reports and Other Evidence and Emirates that are typically scientific. The knowledge of the judge is relevant as defined in the Islamic Penal Code and according to Article 212 of the same law, in case of conflict, it takes precedence over other arguments. In addition, by order of Article 362 of the Code of Criminal Procedure, the court, in addition to the evidence contained in the indictment or the evidence cited by the parties and other evidence and statistics in the case, conducts any investigation necessary to discover the truth. These two legal provisions state the authenticity and subjectivity of the judge's knowledge and its precedence over other evidence of the crime.

\section{The right of ijtihad for judges}

During the Rashidun caliphate, the separation between the executive ruler and the judiciary in the Islamic government was one of the basic principles of the Islamic system. As many Islamic judges stipulated with the caliphs of their time that they would accept the position of judge if their freedom and independence were preserved and no factor other than right and justice interfered in their work. In the early days of Islam, rulers and caliphs observed their limits in the independence 
of the judge. In many cases there was a difference of opinion between the judge and the caliph; Nevertheless, the caliph expressed only his opinion and refused to exercise political will on the judge. The second caliph met a man during his caliphate and said to him: Are we industry? (What did you do?) And the man said: Ali (AS) and Zayd (RA) judged me with such a verdict, Omar said: If you were Anna, you would judge me (if I were you, I would judge with another verdict). The man said: There is no obstacle, you are the ruler. Omar said: If you are a duck to the Book of God and to the Sunnah of the Prophet (PBUH), do not act and do not understand to a common opinion and opinion. (If I had referred you to the Qur'an and the Sunnah of the Prophet, I would have done so, but now I will turn you back to my own opinion and ijtihad, and that (right of ijtihad) is common among all mujtahids (Shahabi, 1372: 82).

The caliph did not invalidate the verdicts of Ali (AS) and Zayd (RA) here, although he was opposed to their ijtihad in judgment. On the other hand, one of the characteristics of a Muslim judge is his release from the confines of his soul, material and sexual prisons, and dangerous worldly attractions. Finally, it must be acknowledged that in Islam, after the establishment of the principle of the independence of the judge and the determination of a sufficient pension for judges, the judge is expected to perform his duties of justice and righteousness properly. For this reason, another principle must be added to the previous principles, and that is that the Islamic government is obliged to monitor the judicial independence and the smooth running of the verdict in favor of the right. In Islam, the principle is to conduct a thorough inspection and thorough investigation of matters belonging to the judiciary and its good conduct; That is, there should be continuous monitoring of the smooth running of the judiciary. All of this oversight is to ensure that the judge is able to restore the right, and that the judge does not exercise his or her taste in adjudicating the case, depending on his or her right to independence.

\section{Evidence for the necessity of ijtihad of judges}

Most jurists believe in the necessity of ijtihad in judging and emphasize this very much. A group of them such as Sheikh Tusi (Bita: 337), Allameh Hali (1422: 5/110), Mohaghegh Hali (1409: 4/860), Martyr Thani (1418: 13/327), Mohaqeq Hali (1410: 271), Shahid Mofid (1410: 721), Ibn Idris (1410: 2/154), Ibn Hamza Tusi (1408: 208), Al-Faqani (1418: 276), Khorasani Sabzevari (1423: 2/660), Hali (1389: 4/298), Halabi (1417: 436) have acknowledged the necessity of knowledge for the judge, but in the description of this adjective or the principles of ijtihad and what is necessary to achieve ijtihad They have not paid or acted according to the fatwas of other scholars. In this regard, Imam Khomeini (ra) and another group of jurists have explicitly mentioned the condition of ijtihad and having the ability (Khomeini, 1390: 2/407; Tabatabai Yazdi, 1423: 6/418; Ameli, 1410: 3/67 The mentioned jurists have presented several arguments to prove their opinion, which we will express.

Narrations: The first is the accepted narration of Umar ibn Hanzala, one of the strongest arguments that has been presented to the judge for the condition of ijtihad; Which we will discuss in the following:

Muhammad ibn Ya`qub on the authority of Muhammad ibn Yahya on the authority of Muhammad ibn al-Husayn on the authority of Muhammad ibn Isa on the authority of Safwan ibn Yahya on the authority of Dawood ibn al-Husayn on the authority of Umar ibn Hanzalah: Salat al-Aba Abdullah (AS) on the authority of his companions among them, quarreled in religion and inheritance. Judgment is the place for you? He said, "I will rule over them in their right and wrong, 
then I will rule over the idolatrous, and we will rule over it, and I will take it, and if it is true, I will firmly take it from the ruler, and we will command God Almighty to say to God Almighty:" Would you like to be led to the tyrant? One of them said to you (women): Fakif Yasnaan said, "I am the one who said, 'I do not think so. On the other hand, God forbid, and he is on the limit of polytheism, by God, he said: If there is a whole unit of free will, men from our companions, suppose that they are the observers in our deception and disagree in our wisdom and their hats differ in your hadith? He said: The ruling is firm on their justice and their affection and their alms in the hadith and their traditions and ...»

The narrator says that I asked Hazrat Sadegh (AS) about two Shiites who had a dispute over debt or inheritance, whether they were allowed to sue the Sultan of the time or the judges of the ruling system. Imam (AS) said in this regard: Whoever pleads with them and takes a lawsuit to them, whether he has a right or not, has sued the Taghut and whatever is ruled in his favor and the money that is It is filthy, even if he is right, because he has taken this property based on the ruling of Taghut, while God has commanded you to disbelieve in Taghut. The narrator says: I said, then what should the two do? Imam (AS) said: Let them see who among you is the narrator of the hadith and who has commented on what is lawful and what is unlawful for us and knows our rules, so let them be satisfied that he is the arbiter, so I have made him the ruler over you and also signed Hazrat Hojjat (AS) is the one who said: And as for the events of the event, they will return to the narration of our hadith, then they are Hojjati to you and I am Hojjatullah (Har Ameli, 1397: 18/98). In this hadith, there are three important interpretations of "Nazar Fi Halalna", "Arf Ahkamna" and "Fiqh" that are applicable to ijtihad, which are described below: In the interpretation of "Nazar Fi Halalna", the word Nazar is interpreted. It is on a person who has been appointed by the Infallible Imam (AS) and must be a person of opinion, and opinion also means thought and reflection, and is not in the imitation of this thought and reflection.

Some elders believe that ijtihad is a condition of judgment, but ruled out the use of the word "opinion" in the condition of ijtihad, including the late Mohaghegh Ashtiani, who states in this regard: The meaning of ijtihad (Ashtiani, 1369: 11). In the interpretation of "the custom of our rules", custom has been considered as the meaning of science, as it is stated in Mesbah al-Munir that the knowledge of knowledge (Fayumi, 1401: 3/98) and in the words of Ragheb: the perception of something by thought (Ragheb, $1409: 4 / 248$ ). In the interpretation of jurisprudence, it is stated that: Our ruling is a ruling on their justice and their jurisprudence (Har Ameli, 1412: 27/205) It is important here that a jurist in Wright does not only mean a mujtahid and a nonmujtahid can also be a jurist ( Naraghi, 1408: 17/25).

As it is clear from this article, none of these interpretations can be a condition of ijtihad for a judge unless it is assumed that the person appointed by the Infallible Imam (as) is a mujtahid; Because in this narration, the narrator of the hadiths of the Ahl al-Bayt and the one who knows what is lawful and what is lawful and their rules have been appointed as "rulers and judges" over the ummah. Is a mujtahid (Ansari, 1415: 29; Sabzevari, Bita: 261) It should be noted that some of them do not accept the assignment of the position of judge to the absolute mujtahid (Ansari, 1415: 30).

The second narration of the news of Abi Khadijeh is: "Muhammad ibn al-Hasan wrote documents ... On the authority of Abi Khadijeh, he said: Abu Abdullah (AS) sent to his companions and said to them, 'If you stand between your adversary or it is dark in what you take and give.' One of the 
hypocrites, do what is lawful and unlawful for us, men, and we are mortal, for you have made me a judge, and I will take some of you to some of them to Sultan al-Ja'ir. "The narrator says: Imam Sadegh (AS) said to me: Do not pray for some of you to pray. Match but look at someone of yours who knows something about our knowledge; So put him among you, a judge, so I made him a judge, so sue him (Har Ameli, 1397: 18/100; Klini, 1363: 7/412)

The reasoning for this narration is similar to the previous narration, and it is believed that the one who knows the teachings of the Ahl al-Bayt (AS) has been appointed as a judge. Because he is the only mujtahid who has knowledge of the rules (Khomeini, 1418: 6/35; Hali, 1413: 2/180).

The third is the narration of Imam Sadegh (AS) who said: Judges are of four groups, three of which are in the fire: the first group is the one who judges with knowledge that he is in the fire and the other is the one who knows unknowingly and out of ignorance. He judges with cruelty that he too is on fire. The third group is the one who rules, although he rules rightly, but out of ignorance and ignorance, and finally, the fourth group is those who judge scientifically while ruling rightly; That this group is in heaven (Har Ameli, 1397: 11/18). Accordingly, the judges of Hell are not the only ones who rule with knowledge, justice and fairness; But there are three other groups in the fire. The statement of the jurists who believe in the necessity of ijtihad of the judge, referring to the previous narration, is that science based on imitation is not actually science because the imitator who rules according to the fatwa of the mujtahid does not know it. ; But the mujtahid who acts according to his inference and rules according to it as a judge, in fact, inferred the ruling from the main evidences and sources and considers it as the ruling of God (Ansari, 1415: 36).

\section{Consensus}

Another reason that has been relied on in order to prove the necessity of the judge's ijtihad is consensus and non-contradiction (Tusi, 1411: 6/208; Shahid Thani, 1419: 2/283; Ansari, 1415: 33). Ibn Zohreh writes in this regard: "It is obligatory for the custodian of justice to be wise in the truth in the ruling of the rejected due to the consensus of the sect and also the guardian of the dead knows that it is ugly rationally and does not allow chapters." It is obligatory for the one who has taken charge of justice to know the truth. The ruling given to him was due to the consensus of the tribe. Also, it is intellectually disgusting to undertake a task that one is not aware of, and it is not permissible for such a person to be hostile. Shahid Thani claims the consensus of the scholars regarding the condition of ijtihad in the judge and goes on to say: The judge must be an absolute mujtahid. In order to be able to occupy the position of judiciary and be hostile (Ameli, 1413: 165) jurists such as Shahid Thani, Sahib Riyadh (Tabatabai, 1419: 138) and Ashtiani (Ashtiani, 1369: 3 ) believe that in addition to verses and hadiths of consensus Indicates the validity of ijtihad in the judge. In this regard, Sahib Jawahir says: There is no consensus that the jurists have claimed that such a consensus does not exist, but it has been proven against us, especially with the emergence of evidence in the validity of the condition of knowledge in the judge that there is no reason for ijtihad in the judge (Najafi, $1412: 40$ ); So such a consensus is not valid in our view because it is a valid consensus that the discoverer of The word of the Infallible (AS). Sheikh Tusi in contrast (Tusi, 1407: 2087) have the interpretation of sectarian consensus, the second martyr in Masalak (Ameli, 1413: 13/329) Ibn Zohreh in Ghaniyeh (Ibn Zohreh, 1411: 437), Feyz Kashani in Mafatih (Feyz Kashani, 1412: 3/236) have claimed consensus and also the Indian genius in the discovery of the third (Indian genius, 1406: 10/7) have claimed consensus; But among the latter, this consensus has not received much attention. For example, in the case of the owner of the jewel, who is very committed to consensus, but in this regard, they have said: But the claim of consensus, 
which was heard by the film, was stopped, but because the researcher was against it (Najafi, 1412: 40). In addition, Sheikh Mofid has mentioned a series of characteristics for the judge that these characteristics apply only to the mujtahid. Of course, he did not mention the word ijtihad, he said: "I do not believe in myself, and I do not believe in any of them, even if I do not even believe in it, I am completely knowledgeable in the book, and the copy, and the abrogated, the public, the private, the deposit, the answer, the court, and the similar mystics." Useful, 1398: 720).

Sheikh Tusi, after Sheikh Mofid, have taken the same phrases from Sheikh Mofid. (Tusi, 1407: 337) Ibn Braj has also stated the attributes of a judge as follows: Judgment is not a contract for a judge except for one who is one of the people of knowledge, justice and perfection, and who is a scholar who is a mystic by the book, the Sunnah, the congregation, the differences and the language of the Arabs ... The book in the tariff on the knowledge of the good, the general, the special, the strong, the similar, the commentator, the absolute, the abrogator, the abrogator and the abrogated (Hali, 1404: 2/597) Judges have deemed it necessary and these descriptions are not applicable to the imitator.

\section{Grateful}

Another reason given by some jurists, including the late Khoei, for the condition of ijtihad is that the condition of ijtihad falls within the realm of the pious, so according to the principle of no personal guardianship over another person, only the mujtahid has his ruling valid and no other ruling is valid. Because the principle of justice is a necessary thing, otherwise the waste of rights, chaos and the destruction of the system of life will be necessary. Therefore, it is necessary that the Imams (AS) have given permission in Qada, but there has been no statement as to who has been given permission by the Infallible (AS). As a result, a matter is established between a mujtahid and a non-mujtahid, in which case the permission of the mujtahid is final and it is doubtful that the principle of non-guardianship of one over another will prevail. This principle of the mujtahid goes beyond the general but the non-mujtahid under this It remains public and as a result the non-mujtahid judgment will not be valid. Of course, the title of proof is the value of the pious due to negligence because it is like a practical principle and its validity is in the absence of reason such as verse, narration, consensus and so on. In other words, the issue under discussion, that is, the condition of ijtihad, is about the period between the matter of determination and change, and in the sense that the holy shari'ah must have given permission to the time of absence, and due to its importance, has not neglected this issue. But there are two possibilities as to who has been given permission; The first is that it is only given to the mujtahids in terms of other conditions such as justice, etc., and the second is that the mujtahids are not allowed in terms of other conditions, of course. If the shari'ah has given general and general permission, that is, both the mujtahid and others are authorized, then the mujtahids are authorized, and if the shari'ah has not given general permission and has given permission only to certain people, then it is not possible to give permission to a non-mujtahid, but Has not given permission to the mujtahid and has considered ijtihad as an obstacle to qada, so it is clear that in this case, too, it is the mujtahid who will be authorized, that is, in any case, it is the mujtahid who is authorized to refer to this type of interpretation. The pious person is a mujtahid. In this regard, the late Khoei, after entering into the narrations as evidence and evidence, went to the value of the pious and considered ijtihad as a condition and placed the mujtahid in the range of the value of the pious and accepted Velayate-Faqih with this principle (Tabatabai Yazdi, 1999). : 6/415). 
No need for ijtihad in judgment

Some jurists, without using the term ijtihad or jurisprudence, have contented themselves with stating that the judge needs to be a scholar. This means that he must be familiar with books, traditions and words. These expressions are mostly seen in the words of earlier jurists (Mufid, 1413: 720; Ibn Hamza, 1408: 207; Ibn Idris, 1410: 155). The late Naraghi pays special attention to this matter and says: The words of most of the ancients are empty of mentioning the mujtahid or its synonym (Naraghi, 1415: 25). Some have explicitly considered ijtihad as a condition in the judge and have given their statement in absolute terms (Hali, 1420: 5/110; Mohaqeq Hali, 1408: 60) and on this point of view, consensus has been claimed (Shahid Thani, 1413: 328; Yazdi, 1409 : 6). Some, such as the first martyr and Ayatollah Khoei, did not consider the consolidation of ijtihad in the consolidation judge as a condition by separating the appointed judge from the judge (Shahid Thani, 1410: 68; Khoei, 1407: 13). Others do not consider ijtihad as an absolute condition and the criterion in their opinion is that the ruling is right and just and based on the rules of the Ahl al-Bayt, even if the judge is not a mujtahid (Najafi, 1981: 40; Muqaddas Ardabili, 1414: 19; Ardabili, 1423: 130). Proponents of her case have been working to make the actual transcript of this statement available online.

Among the arguments cited by this group are the narrations that have been proposed about the chapter of hostility, such as the narration of Halabi (Har Ameli, 1409: 27). In this narration, the phrase "Fitrazians of the tower of Mina" is mentioned and approved by the Imam, and jurisprudence is not mentioned in it. Therefore, the emergence of the narration in the absence of a jurist, the man in question, is clear Because if he was one of the Shiite jurists, Halabi's question would be asked and it was clear that referring to him is not referring to Taghut and it is unlikely that Halabi's character would have asked such a question. Another narration that has been cited is the narration of Abu Khadijeh, who says: Imam Sadegh (AS) sent me to the Shiites and said to them: Tell them: Whenever there is enmity between you or a dispute arises between you, do not go to these transgressors for trial, but Make a man among you a judge who knows our lawful and unlawful rulings, then I have made him a judge over you (Har Ameli, 1409: 27). This hadith is also considered valid from the point of view of the document (Momen, Bita: 64). In this hadith, Imam (AS) said about a worthy judge: "The custom of lawful and unlawful", which includes a non-mujtahid who knows what is lawful and unlawful by imitating a mujtahid, and Imam (AS) has considered his judgment and judgment to be correct. In addition, some jurists consider it permissible to judge the imitator absolutely, that is, both in times of discretion and in times of urgency. However, in his opinion, in order to be in this position, the imitator must have the permission of a comprehensive mujtahid who, according to the texts and consensus, is considered the successor and deputy of the Imams, otherwise his judgment will not be permissible. Among the jurists who have acknowledged this matter, we can mention Sahib Jawaher (15/40), Seyyed Abdul Karim Mousavi (1408: 89), Seyyed Mohammad Hosseini Shirazi (1401: 1/22) and Mohammad Hassan Haeri Yazdi (73).

\section{The subject of ijtihad of judges in the current judicial system}

In the current judicial system and according to the constitution, the judge is obliged to issue judicial rulings and rulings according to the law and based on it, and if he does not find the ruling of the lawsuit in the laws, even if he is a mujtahid, he cannot issue the ruling according to his fatwa. Article 167 of the Constitution of the Islamic Republic of Iran stipulates that: The judge is obliged to try to find the verdict of any lawsuit in the codified laws and if he does not find it, he 
can issue the verdict based on valid Islamic sources or fatwas and cannot use it as an excuse. Silence or defect or conciseness or conflict of laws refuses to hear the case and issue a verdict.

As it turns out, the legislator did not give the judge the right to act on his fatwa if he was a mujtahid, even if he did not find a ruling in the laws. However, in cases where the judge is a mujtahid and considers the law to be against the Shari'a, he is given the right to refuse to hear the case in that case so that the case can be referred to another branch of the court.

Accordingly, Article 3 of the Code of Civil Procedure of the General and Revolutionary Courts in Civil Matters and its Note stipulate that: Judges of the courts are obliged, in accordance with the law, to hear cases, issue an appropriate verdict or a chapter on hostilities. If the laws in question are not complete or explicit or are contradictory or there is no law in the case at all, based on valid Islamic sources or valid fatwas and legal principles that are not contrary to Islamic law, they can issue a verdict and can not use it as an excuse. Silence or defect or conciseness or conflict of laws, refuse to hear the case and issue a verdict, otherwise they will be deprived of the realization of the recognized right and will be sentenced to punishment.

And in its note, it is stated that if the judge is a mujtahid and considers the law to be against the Shari'a, the case will be referred to another branch for consideration. In fact, this article, and especially its commentary, prevents the issuance of a judicial verdict in accordance with the fatwa of the Mujtahid judge, and the judge cannot issue a verdict in accordance with his ijtihad opinion and fatwa, assuming that the law, considering his fatwa, is unlawful. Slow; Rather, he is given only the right to refuse to hear the case until another branch of the court hears the case and issues a verdict in accordance with the law, and in the absence of a verdict in the laws, he can only refer to authentic Islamic sources or valid fatwas. And refer to legal principles that are not contrary to the Shari'a and issue a ruling based on them.

The judge can make his own inferences within the limits of codified laws, conflict resolution, summarizing laws and his interpretation of the text of the law, provided that in that case, a unanimous decision has not been issued. According to Article 161 of the Constitution, this task is the responsibility of the Supreme Court. It is a country, otherwise it will be obliged to follow the unanimous decision of the procedure issued by the Supreme Court.

Also, according to Article 173, the interpretation and interpretation of ordinary laws is within the competence of the Islamic Consultative Assembly. The provisions of this principle do not preclude the interpretation that judges make of the law as a pure right. In addition, Article 170 of the Constitution provides: Judges of the courts are obliged to refrain from enforcing government decrees and regulations that are contrary to Islamic laws and regulations or outside the powers of the executive branch, and anyone can revoke such provisions from the Court of Administrative Justice. To request that in order to recognize such a thing and based on the evidence and texts, the judge must be familiar with the principles, rules and foundations of the Islamic legal and judicial system in order to be expected to do so. Therefore, while believing in the theory of non-necessity, we believe that non-mujtahid judges should also have a relative mastery of jurisprudence and the principles of Islamic law. Article 163 of the Constitution stipulates that: The attributes and conditions of a judge shall be determined by law in accordance with jurisprudential standards. In the implementation of this principle, paragraph 5 of the single article of the law stipulates the conditions for the election of judges of justice: "... having ijtihad or permission to judge ..." and to those who have a law degree or theology degree in jurisprudence and the principles of Islamic 
law or students After completing the level, they have spent two years outside of jurisprudence and jurisprudence and have been allowed to volunteer for this position; Therefore, in the current laws and procedures of the country's judiciary, the mujtahid is practically an evil judge It is not considered necessary to hold the position of judge.

\section{Conclusion}

\section{Jurisprudential and legal review of judges' independence}

One of the basic principles of judgment in Islam is the well-known principle of judicial independence, which is also referred to as the foundation and main concept of justice. In some verses of the Holy Quran, such as verse 135 of Surah An-Nisa ', judicial independence is mentioned, which indicates the importance of this vital principle; One of the important conditions of judicial independence is the independence of the judge, and personal independence in this study means the release of the judge from any pressure. Freedom of the judge from external pressures means independence from relatives, friends, litigants, those in power, public opinion, colleagues and those who run the judiciary. And the purpose of judicial independence is for the judge to use the law as a criterion for ruling and not to pay attention to the orders and influence of his superiors, and in addition that others should not remove him from office, demote him or change his place of service. On the other hand, they should not be afraid of these things. This means that these matters should not affect him. It is also clear that judicial independence, like other legal institutions, follows the general goal of law, namely the administration of justice on the basis of order, and is also a scene of conflict between order and justice because most violators of this principle are the providers of social order and under the pretext of independence. They are attacking the judiciary. The principle of judicial independence is one of the most important legal principles regarding judging, which can be understood with a little care in its meaning and basis, in addition to providing two main goals of order and justice in law; In particular, it has three other important benefits: protecting the rights of society; Ensuring the rights of the judiciary and guaranteeing individual rights. However, a review of the legislative background and its developments in Iran shows that despite the importance of the independence of the judge in the conduct of a fair trial, not only has not been properly considered, but in the legislative process has always seen the expansion of authority. We are government agencies with different titles in order to limit the independence of judges. It seems that the laws and regulations related to judges from the perspective of employment and promotion and promotion, job security, how to prosecute and investigate violations, accreditation to vote, interpretation and opinion of the judge, in order to guarantee and Respect for the independence of the judge needs to be reconsidered and reformed, and without addressing this issue, it is not possible to talk about the independence of the judge in its true sense. It's worthy; The legislator should try to improve the principles of independence and neutrality quantitatively and qualitatively and should observe these principles. On the other hand, it is expected that the legislator, by passing comprehensive and preventive laws, in addition to guaranteeing the proportionate execution of the crime, will act against the right of the judge, which is contrary to the principle of impartiality, and from advising and influencing judicial officers. And to prevent an administration that violates the principle of judicial independence. In general, the legal system of our country suffers from weaknesses and shortcomings both in terms of structure and in terms of principles and procedures; In a way that the independence and impartiality of the judge is seriously questioned. Therefore, in order to complete and develop the judicial justice system as much as possible, it is proposed to create independent and impartial courts in order to ensure the principle of equality of arms while accepting the supervision of judges and the punishment of the offending judge. 


\section{Jurisprudential and legal study of the science of judges}

Evidence of crime is one of the most important issues in criminal law and criminal procedure. Prior to the enactment of the Islamic Penal Code in 1392, the issues related to this issue were inconsistently mentioned in the Penal Code and the Code of Criminal Procedure. In fact, the former legislature did not consider an independent law on proof in criminal matters. Rather, the issues related to proof were expressed in a scattered and incoherent manner in the Islamic Penal Code of 1991 and the Code of Criminal Procedure. And this issue caused various disagreements about the system of probative reasons accepted by the legislator, how to decide if there is a conflict between different arguments, the meaning of the judge's knowledge and so on. With the approval of the Islamic Penal Code in 2013 and the allocation of a separate part of this law to the evidence, many of the mentioned problems were solved and effective measures have been taken by the criminal legislator. In particular with regard to the knowledge of the judge, which is the subject of the present study, the measures taken by the legislature have covered many of the past ambiguities. Thus, from the content of the articles regulated in this regard, it can be clearly understood that the legislator does not mean science as a definite logical science, but as a science derived from the reasons, documents and documents in the criminal case. Evidence in criminal matters, the fifth part of the first book of this law, which itself consists of five chapters, is dedicated to evidence in criminal matters and the legislator in this section discusses the most important evidence and rules governing their presentation and application in criminal authorities. And has removed the confusion of judges that they have previously encountered in the discussion of evidence. Another issue that can be considered specifically in the discussion of judge science as an innovative approach to solving the existing problems in this field is the concept that the criminal legislator has presented of judge science. The legislator stipulates in Article 131 of the Islamic Penal Code of 1392 that "the knowledge of a judge is the certainty obtained from the documents in the matter that is presented to him." In cases where the document of the verdict is the knowledge of the judge, he is obliged to correctly state the evidence and the UAE between the document of his knowledge in the verdict. "As is clear from this definition, the legislator addresses the existing disputes over the meaning of science. Judge is personal knowledge or end knowledge اده است be the certainty obtained from the documents in the matter before him, and the knowledge obtained from the documents can not be the personal knowledge of the judge of the case. In addition, in the following part of this article, the criminal legislator has obliged the judge to explicitly state the evidence and the UAE between the document of his knowledge, and of course the evidence and the UAE can not only contain the personal observations or hearings of the judge. Be. In addition, the commentary on Article 211 can be cited. The legislator has been trying to explain his meaning of the documents and has stated that "items such as expert theory, site inspection, local investigations, informed statements, officers' reports and other evidence "And the UAE, which is typically knowledgeable, can be documented as a judge." Therefore, it can be inferred that the meaning of the documents between is the cases that can be included in the criminal case and can be reviewed by higher authorities. It seems that accepting this opinion and invalidating the personal knowledge of judges is more compatible with the criteria of a fair trial and the necessities related to the defense rights of the defendants, and will especially provide the basis for documenting the knowledge of judges at higher stages of criminal proceedings. Therefore, citing personal knowledge is not allowed for the judge of the court. The judge's personal knowledge refers to his personal information and information that he has obtained 
outside the contents of the case and has no appearance in the case file and the evidence presented in court. Judge's knowledge is one of the topics of controversy among jurisprudence and law experts. What we have reached about the nature of the judge's knowledge in this study is that the expressions in Articles 211 and 212 of the Islamic Penal Code of 1392 indicate that from the legislative point of view, what is the basis for producing knowledge for the judge is evidence and the UAE typically The science is the result of judicial research.

\section{Jurisprudential and legal study of judges' ijtihad}

The matter of jurisprudence in religious texts is considered very serious and originally considered as one of the characteristics of the Holy Prophet (PBUH) or the guardian of the Holy Prophet (PBUH). Ijtihad in judges is an undeniable virtue and non-mujtahid judges must be familiar with the jurisprudence and rules of Islam, which is the basis and support of the judicial system and current laws, and be able to adapt to current examples and deduce from the law to an acceptable level. Have the authority to hold this serious position. He has been widely criticized for holding incompetent people in charge of this position (Nahj al-Balaghah, 17); But during the absence of Imam al-Asr (as) when society is inevitably a judge, this duty has been entrusted by the Imam to the scholars and the teachings of the Ahl al-Bayt and has been generally delegated to them (Har Ameli, 1397: 18). : 99). This has caused the Shiite jurists to consider "ijtihad" as a necessary condition and the jurisprudence as one of the affairs of the fatwas (Tabatabai, 1412: 2/385; Shahid Thani, 1419: 3/60; Salar, 1414) : 230; 420/3:1413 (حلى). Most jurists believe in the necessity of ijtihad in judging and emphasize this very much. A group of them such as Sheikh Tusi (Bita: 337 ), Allameh Hali (1422: 5/110), Mohaghegh Hali (1409: 4/860), Martyr Thani (1418: 13/327), Mohaqeq Hali (1410: 271), Shahid Mofid (1410: 721), Ibn Idris (1410: 2/154), Ibn Hamza Tusi (1408: 208), Al-Faqani (1418: 276), Khorasani Sabzevari (1423: 2/660), Hali (1389: 4/298), Halabi (1417: 436) have acknowledged the necessity of knowledge for the judge, but in the description of this adjective or the principles of ijtihad and what is necessary to achieve ijtihad They have not paid or acted according to the fatwas of other scholars. In this regard, Imam Khomeini (ra) and another group of jurists have explicitly mentioned the condition of ijtihad and having the ability (Khomeini, 1390: 2/407; Tabatabai Yazdi, 1423: 6/418; Ameli, 1410: 3/67 ).

But from a legal point of view, Article 167 of the Constitution of the Islamic Republic of Iran states that a judge is obliged to try to find the verdict of any lawsuit in the codified laws and if he does not find it, to issue a verdict based on valid Islamic sources or fatwas. He may not refuse to hear a case or issue a sentence under the pretext of silence or defect or brevity or conflict of laws. As it turns out, the legislator did not give the judge the right to act on his fatwa if he was a mujtahid, even if he did not find a ruling in the laws. However, in cases where the judge is a mujtahid and considers the law to be against the Shari'a, he has been given the right to refuse to hear the case so that the case can be referred to another branch of the court. Accordingly, Article 3 of the Code of Civil Procedure states that the judges of the courts are obliged, in accordance with the law, to hear cases, issue appropriate judgments, or adjudicate hostilities. If the laws in question are not complete or explicit or are contradictory or there is no law in the case at all, based on valid Islamic sources or valid fatwas and legal principles that are not contrary to Islamic law, they can issue a verdict and can not use it as an excuse. Silence or defect or conciseness or conflict of laws, refuse to hear the case and issue a verdict, otherwise they will be deprived of the realization of the recognized right and will be sentenced to punishment. And in its note, it is stated that if the judge is a mujtahid and considers the law to be against the Shari'a, the case will be referred to another branch for consideration. As is clear from the context of Article 3 of the Code of Civil Procedure of the General and Revolutionary Courts in Civil Matters and its commentary, 
this article, and in particular its commentary, prevents the issuance of a judicial verdict in accordance with the fatwa of the Mujtahid judge, and the judge cannot Considering his fatwa, he found it against the Shari'a, according to the ijtihad opinion and To issue a fatwa; Rather, he has only been given the right to refuse to hear the case so that another branch of the court can hear the case and issue a verdict in accordance with the law. In addition, Article 170 of the Constitution stipulates that judges of the courts are obliged to refrain from enforcing government decrees and regulations that are contrary to Islamic laws and regulations or outside the jurisdiction of the executive branch, and anyone can revoke such provisions from the Court of Justice. The administration should request that in order to determine such a matter and based on the evidence and texts, the judge must be familiar with the principles, rules and foundations of the Islamic legal and judicial system in order to be expected to do so.

Therefore, while believing in the theory of non-necessity, we believe that non-mujtahid judges should also have a relative mastery of jurisprudence and the principles of Islamic law. Article 163 of the Constitution stipulates that: The attributes and conditions of a judge shall be determined by law in accordance with jurisprudential standards. In the implementation of this principle, paragraph 5 of the single article of the law stipulates the conditions for the election of judges of justice: "... having ijtihad or permission to judge ..." and to those who have a law degree or theology degree in jurisprudence and the principles of Islamic law or students After completing the level, they have spent two years outside of jurisprudence and jurisprudence and have been allowed to volunteer for this position; Therefore, in the current laws and procedures of the judiciary of the country, the fact that a judge is a mujtahid has not been considered a necessary condition for holding the position of a judge.

\section{References}

Ashtiani, Mirza Mohammad Hassan bin Jafar. (1369).Tehran: Rangin, first edition.

Ansari, Morteza bin Muhammad. (1415). Judgment and martyrdom. First edition.

Iron, Batool. (1381). Validity of the judge's knowledge in issuing the verdict. Nedaye Sadegh Magazine, 7 (25).

Ibn Rushd, Muhammad ibn Ahmad. (1415). The beginning of the mujtahid and the end of the intended, Volume 2. Beirut: Dar al-Fikr.

Ibn Qadameh, Abdul Rahman. (Without). Beirut: Dar Al-Kitab Al-Arabi.

Amiri, Abtin. (1392). The importance of judgment and independence of judgment in Islamic law. Quarterly.

Amiri, Mohsen; Special, Mohammad Reza (1393). Basic principles governing the guarantee of judicial independence in the Iranian legal system with a view to French law.

Tavassoli Naeini, Manouchehr. (1385). Occupational immunities in Iranian law. Journal of Fundamental Rights 
Jabai Ameli, Zayn al-Din bin Ali (Shahid Thani). (1386). Al-Rawdha al-Bahiyya fi Sharh alLama'ah al-Damashqah, research by Sayyid Muhammad Kalantar, Volume 6. Beirut: Dar al-Ta'rif Press, first edition.

10. Jafari Langroudi, Mohammad Jafar. (1372). Legal terminology. Tehran: Ganjudanesh Publications, 6th edition

Jafari Langroudi, Mohammad Jafar. (1386). Based on Legal Terminology, Volume 1. Tehran: Ganj-e-Danesh Library, Third Edition.

Jafari Langroudi, Mohammad Jafar. (1385). Islamic law. Tehran: Ganj Publications.

Jafari Langroudi, Mohammad Jafar. (1370). Law schools in Islamic law. Tehran: Ganj-e-Danesh Publications.

Jafari Langroudi, Mohammad Jafar. (1367). Encyclopedia of Law, Volume 4. Encyclopedia of Islamic Sciences. Tehran, first edition.

Hosseini Nejad, Hossein Ali. (1370). Civil liability. Tehran: Cultural Department of University Jihad, Shahid Beheshti University.

Habibzadeh, Mohammad Jafar; Essie, Angel. (1387). Judicial immunity of judges and attorneys in the Iranian legal system. Law Quarterly, 38 (4), 183-161.

Sheikh Tusi. (Without). Al-Tibyan Fi Tafsir Al-Quran, Volume 4, Investigation by Ahmad Habib Qusair Al-Ameli. Najaf Ashraf: Scientific Press.

Shokani, Muhammad ibn Ali. (1413). Nil al-Awtar, Volume 8. Egypt Dar al-Hadith.

Salehi Mazandarani, Mohammad. (1384). A Reflection on the Civil Liability of a Judge in Article 171 of the Constitution. Journal of Jurisprudence and Law, (7).

Tabatabai Yazdi, Seyed Mohammad Kazem. (1378). The margin of achievement. Qom: Ismailian Institute, 1 st edition.

Tabatabai Yazdi, Seyed Mohammad Kazem. (1423). Al-Urwah Al-Wathqi, Volume 6. Qom: Islamic Publishing Institute for the Association of Teachers, First Edition.

Tabatabai, Seyed Ali. (1412). Riyadh issues in the expression of the arguments for reasons. Beirut: Dar al-Hadi.

Barak, Aharon. (2006). the Judge in a Democracy. Princeton: Princeton University Press. 